\title{
Cash Flow Restatements: Stock Market Reaction to Overstated versus Understated Restatements
}

\author{
Elio Alfonso ${ }^{1}$, Dana Hollie ${ }^{2} \&$ Shaokun Carol $\mathrm{Yu}^{3}$ \\ ${ }^{1}$ Assistant Professor of Accounting, University of Tampa, United States \\ ${ }^{2}$ Associate Professor of Accounting, Alan and Karen Barry Endowed Professor of Accounting, University of Toledo, \\ United States \\ ${ }^{3}$ Associate Professor of Accounting, Northern Illinois University, United States \\ Correspondence: Dana Hollie, University of Toledo, United States
}

Received: May 6, 2019

Accepted: May 23, 2019

Online Published: May 24, 2019

doi:10.5430/afr.v8n3p1

URL: https://doi.org/10.5430/afr.v8n3p1

\begin{abstract}
The Securities and Exchange Commission has become increasingly concerned with the rising number of restatements to statements of cash flows (SCFs). Regulators and practitioners are generally more focused on the overstatement of operating cash flows, while the understatement of operating cash flows is often overlooked but may have the same (or more) negative economic consequences. We examine market reactions to cash flow restatements (CFRs) where firms overstate or understate cash flows from 2000 to 2013 . This study finds that $41 \%$ of firms overstated operating cash flows, while a surprising $48 \%$ understated operating cash flows. While we find that the market does not react to overstated operating cash flows or overstated total cash flows (TCFs), we find a negative response to understated operating cash flows and understated TCFs. Interestingly, the market penalizes these firms more for understating rather than overstating cash flows. There is a CFR disclosure post-announcement drift in abnormal returns that occurs for both understated operating and understated TCFs. We provide evidence that the often-overlooked understated CFRs may have "real" economic consequences and that they should be evaluated further and given the same consideration as overstatements by auditors, regulators, and investors.
\end{abstract}

Keywords: cash flow restatements, cash flows, cash flow misclassifications, statement of cash flows

\section{Introduction}

The statement of cash flows (SCF) is one of the primary financial statements required in accordance with Generally Accepted Accounting Principles (GAAP). The Statement of Financial Accounting Standards (SFAS) No. 95, Statement of Cash Flows, issued in November of 1987 by the Financial Accounting Standards Board, specifies the content and composition of the statement. The American Institute of Certified Public Accountants (AICPA), Financial Accounting Standards Board (FASB), Public Company Accounting Oversight Board (PCAOB), and the Securities and Exchange Commission (SEC) have all expressed that the accounting profession needs to focus more on the SCFs (Audit Analytics Trend Report, 2013). Unfortunately, the percentage of restatements of the statement of cash flows has risen from $8.7 \%$ of all restatements in 2009 to almost $20 \%$ in 2013, and it continues to rise. The reasons for restatements vary, but most do not involve complex determinations of underlying cash flow problems. Many of the issues in the SCFs have been related to misclassifications (i.e., classification shifting). Consequently, the FASB acknowledged issues with the SCFs that they had neglected and created an Emerging Issues Task Force in 2015 to consider nine primary issues related to the SCFs. The result of the task force was an Accounting Standards Update No. 2016-15 on the Statement of Cash Flows (Topic 230) issued in August of 2016 (effective after December $15,2017)$. This update was intended to address eight specific issues with the objective of reducing the existing diversity in practice when assessing the SCF, thereby reducing the number of cash flow restatements (CFRs). More recently, the FASB added Update No. 2016-18 to provide guidance on restricted cash presentation, transfers to and from restricted cash, and disclosure of the nature and amount of restrictions on cash and cash equivalents. Additionally, the SEC called for companies to tighten accounting procedures and controls pertaining to the SCFs. The PCAOB noted the same issue and hired inspectors to evaluate auditors' testing of the SCFs. Misclassifications on the SCF pose a presentation problem that affects a firm's financial reporting transparency and is still an issue for regulators. 
The current research on CFRs has primarily focused on firms overstating CFOs. Our study focuses on both firms that overstate and firms that understate operating and total cash flows. (Note 1) An understatement is just as problematic as an overstatement because it is an inaccurate reporting of the SCF that may affect a financial statement user's interpretation of the financial well-being of a firm. We focus on descriptive statistics to identify firm characteristics of firms that overstate versus understate cash flows and how the capital markets respond to these CFRs. We also contribute to the literature by providing evidence as to whether there are economic consequences related to these two types of CFRs. As one of the first studies to focus on the understatement of CFOs in CFRs, this study is somewhat exploratory in nature. However, this study contributes to our collective understanding of when firms might report a $\mathrm{CFR}$, as well as economic consequences of misreported cash flows.

Using a sample of CFRs (i.e., restatements without any concurrent earnings or balance sheet restatements), we examined characteristics of firms that overstate or understate CFO. We then assessed the market's response to these CFR disclosures. (Note 2) In our sample of 225 CFRs disclosed from 2000-2013, 46\% (54\%) of firms with overstatements (understatements) had downward (upward) restatements to CFO. Approximately $38 \%$ of our observations did not disclose a change from the originally reported to the restated amount of total cash flows (TCFs), which suggests that likely only classification shifting occurred in the SCF. (Note 3) The other 62\% reported a nonzero change to TCF. We found that the market reacts negatively to firms that understate CFO or understate TCF. However, our post-announcement drift results suggest that this immediate negative reaction is incomplete. It appears that some investors may not form an unbiased expectation of future cash flows upon disclosure of an understated CFR, but they then positively update their expectation of future cash flows over the next six to twelve months. On the contrary, we did not find that investors react significantly to CFO overstatements. We also found that the market reacts negatively to CFRs that include a change in TCFs. Again, the market reversed its valuation and indicated a net positive reaction over the next six to twelve months. Our empirical findings suggest that the market is initially more unforgiving to firms that understate their CFOs or TCFs than to those that overstate them. Our results suggest that it is just as important to focus on firms with understated cash flows as those that are overstated. Hence, there are real economic consequences associated with understatements that may have been and continue to be overlooked in practice and the literature. And, the understatement of both CFOs and TCFs can be important to investors in firm valuation.

Regardless of whether a firm has a negative or positive change to CFOs or TCFs, these changes are an indication of poor-quality financial information. Our results are particularly relevant to academics, financial analysts, regulators, and investors. Our results are important to academic researchers because CFRs have been sparsely studied in the academic literature. Our evidence suggests that investors should pay close attention not only to overstated CFRs but also to understated CFRs. From a market perspective, investors and financial analysts should pay particular attention when understatements to cash flows occur, because a post-announcement drift follows this type of disclosure. Lastly, our results have important implications for accounting regulators because our results show that the capital markets are differentially impacted by the type of CFR (understatement versus overstatement) reported by publicly traded firms.

\section{Background and Related Literature}

\subsection{Background on Cash Flow Restatements}

Investors have traditionally relied primarily on the balance sheet and income statement, thereby focusing more on companies' earnings than their cash position. However, accounting scandals in the last couple of decades have changed the landscape of Wall Street. Investors have seen how earnings can be manipulated, so now they are focusing more on other metrics, such as cash flows. The SCF allows investors to better understand a company's operations, its sources of cash, and how cash is spent. To the extent that management uses discretion to opportunistically manipulate accruals, earnings will become a less reliable measure of firm performance, and cash flows will become the more reliable and preferred performance metric. Not only will a firm with a more reliable and transparent SCF be more aware of its financial standing, but the SCF will also help investors to make educated decisions regarding future investments. A firm that reports positive CFO exhibits more economic solvency and is more attractive to investors than a firm with negative CFO.

Before 2006, the SEC had not announced any new regulation concerning the SCF since 1987, when the FASB issued SFAS 95, Statement of Cash Flows, which required companies to issue an SCF as opposed to a statement of changes in financial position. Even then, the FASB encouraged companies to use the direct method rather than the indirect method, but they did not, and still do not, require it. As opposed to the large number of guidelines available concerning earnings reporting, SFAS 95 focuses only on the classification of cash expenditures into three categories 
of cash activities: operating, investing, and financing. The lack of guidance allows companies to use some discretion to misclassify items under these three categories. Many firms have been using this misclassification to improve the perception of their cash flow situation. The SEC has also maintained that the proper classification of cash flows gives financial statement users insights into how a firm generates and uses cash flows. We focused on the CFO component of the SCF, because CFO is generally the focus for investors, analysts, and auditors. For example, analysts' cash flow forecasts typically forecast cash flows from operations.

Over the last two decades, many of the companies that restated their SCFs did so because of a misclassification of cash flows in their SCF. As a result, in 2006, the SEC announced a one-time allowance for firms with erroneous SCF classifications to correct their misstatements without officially restating their cash flows. Hollie et al. (2011) assessed the impact of this one-time allowance. They found that, consistent with the SEC's concerns, firms generally overstated cash flows from operations and understated cash flows for investing activities, thereby misrepresenting cash flows; the most frequent line-item reclassifications echoed the SEC's concerns about the presentation of discontinued operations and dealer-floor plan financing arrangements. However, insurance claim proceeds and beneficial interests in securitized loans appeared less problematic than the SEC expected. Their results also indicate that the SEC's plan to mitigate some of the expected negative market reaction for CFRs, in the SEC's allowance period, was relatively successful. Lastly, they find that the firms' CFR disclosures exerted only a marginally negative impact on these firms' stock prices.

\subsection{Related Research on Cash Flows}

Regulators and prior research have found that investors have suffered significant losses as market capitalizations have dropped by billions of dollars due to earnings restatements (Levitt, 2000; Palmrose et al., 2004; Chen et al., 2017; Drakopoulou, 2018; Wan, 2018). As a result of corporate scandals including Enron and WorldCom, market participants have an increasingly greater demand for cash flow information in valuing securities. Prior research has found that when the earnings numbers become less reliable, investors turn to more reliable financial metrics such as cash flows (Defond \& Hung, 2003; Wasley \& Wu, 2006; Call, 2008; Lee, 2012; Ball et al., 2016; Lail \& Martin, 2017). Consistent with this increase in demand for cash flow information, studies such as that by Wasley and Wu (2006) have found that financial analysts' cash flow forecasts have more than doubled from pre-2000 levels. Despite this increasing trend toward investors' using more cash flow information, there is little research on CFRs compared to that on earnings restatements.

There is limited prior literature as it pertains to cash flow restatements. More specifically, we focus on the type of restatement (overstated versus understated). Even though cash flows are viewed as a fundamental performance measure for valuing a firm (Penman, 2001), a majority of the literature has been related to earnings (Bowen et al., 1987; Ali, 1994; Dechow, 1994; Barth et al., 2001, Barth et al., 2016; Hairston et al., 2019). However, analyzing a firm's cash flows is important because cash flows are a vital component of value relevance (FASB, 1978; Barth et al., 2001). We focus on the association between CFR disclosures and market reactions to this type of disclosure.

Within the accounting profession and among regulators, the debate about the proper format of the SCF may have contributed to the current classification error dilemma. When finalizing the reporting requirements for the SCF, the FASB included interest-related cash flows in the operating section. However, the AICPA had suggested reporting interest payments as a non-operating cash flow item. The inconsistencies arising when firms report their cash flows in accordance with SFAS No. 95 have been the focus of several studies. For example, Nurnberg (1983) identified several ambiguities within the SCF, while Nurnberg and Largay (1996) identified differences in classifying similar cash flows that may be difficult to resolve. They also provided evidence that disclosing the nature and reasons for classification policies may enhance cash flow statement comparability and utility. Other studies have examined the economic implications of the cash flow statement components (e.g., Barth et al., 2001; Cheng \& Hollie, 2008; Luo, 2008).

Another series of studies (Mulford \& Martins, 2004, 2005a, 2005b) closely examined individual cash flow reporting practices at several publicly traded companies. Mulford and Martins (2005) outlined the cash flow problems associated with customer-related notes receivable (e.g., dealer-floor plan financing), sales-type lease receivables, and franchise receivables. They documented several companies that classified changes in these types of receivables as investing cash flows, and they argued for their reclassification as CFOs. Mulford and Martins' studies predate the SEC's actions related to cash flow reclassifications and have been credited with assisting the SEC in focusing on the issues outlined by Hollie et al. (2011), as well as this study.

In 2004 and 2005, Chuck Mulford led a charge to make companies pay more attention to how firms classify cash flows, which prompted the SEC, in 2006, to allow firms to correct their misclassifications in their next filing period without 
having to formally restate the SCF. Hollie et al. (2011) investigated the SCF reclassifications during this period. They examined a unique setting in which the SEC allowed management to avoid penalty for reclassifying its cash flows during a specified period. They also examined the reclassifications resulting from the SEC's increased scrutiny of cash flow reporting during the allowance period. To assess the impact of these reclassifications, they determined the types of firms affected by this allowance and the types of reclassifications in the operating, investing, and financing categories of the cash flow statement. Consistent with the SEC's concerns, they found that firms were overstating net CFOs and understating net investing cash flows, thereby misrepresenting cash flows. The most frequent line-item reclassifications were consistent with the SEC's concerns about the presentation of discontinued operations and dealer-floor plan financing arrangements. Insurance claim proceeds and beneficial interests in securitized loans appeared to be less problematic than the SEC expected. Overall, their evidence indicated that the SEC's plan to mitigate negative market effects was relatively successful for firms that took advantage of the allowance period to restate cash flows.

Lee (2012) examined firms that inflated reported CFO in the original SCF and the mechanisms through which firms manage CFO. She found that, even after controlling for the level of earnings, firms upward manage reported CFO when the incentives to do so are particularly high. Specifically, she found that firms manage CFO by shifting items between the CFO categories both within and outside the boundaries of GAAP, by timing certain transactions such as delaying payments to suppliers or accelerating collections from customers. She focused only on firms with overstated CFRs.

Alfonso et al. (2017) examined the determinants and economic consequences of CFRs of firms that overstate CFOs. They found that firms are more likely to issue a CFR when they have analysts' cash flow forecasts, discontinued operations, dividend issuances, more segments, are growth firms, and are larger in size. They also found a significant trading volume reaction and a negative abnormal price reaction to changes in CFOs for firms that overstate CFRs.

While prior research has mostly focused on overstated CFRs, this is the first study to focus on both overstated and understated restatements of the SCF. Second, we distinguish between firms with classification shifting (which refers to firms that do not have changes to TCF after a restatement) and firms without classification shifting that results in a change to TCF. If the restatement is purely a function of misclassification (whether intentional or not), we would expect TCF to remain the same after the restatement. Third, we then assess the market's response to these types of CFR disclosures.

\subsection{Characteristics of Cash Flow Restatements}

First, we examine the firm characteristics between firms who overstate versus understate cash flows. Because CFOs are often viewed as a performance benchmark incremental to earnings, managers may have incentives to overstate CFO. If earnings are significantly greater than CFO, investors often assume that managers may be using upward earnings management. This was a major motivation for many companies to shift financing inflows to the operating section and to shift operating outflows to the investing section to increase CFO. Because firms do not usually report the exact cause of the CFR, it is difficult to ascertain whether a restatement is due to an error or an irregularity. Our study is an important early step in understanding the underlying characteristics for the types (i.e., overstated or understated) of CFRs. We use characteristics referenced in the literature, which encompasses academic, practitioner, and anecdotal evidence on cash flows and, to some extent, earnings restatements.

Specifically, we analyze the following firm characteristics: average total assets, discontinued operations, current ratio, total accruals, debt, return on assets, change in earnings-cash flow ratio, firm size, market-to-book ratio, book-tax difference, free cash flow, firm distress, dividends, Big N auditor, meet or beat earnings benchmark indicator, cash flow forecast indicator, and number of business segments. Debt is likely to be related to CFRs because firms have some degree of flexibility under SFAS No. 95 in classifying interest payments, and managers have certain incentives to inflate CFOs (Lee 2012). Current ratios can be influenced by managers adjusting the level of cash and by misclassifying cash flows to avoid debt covenant violations. The number of segments is related to CFRs because complex firms sometimes use their flexibility in classifying cash flow activities to inflate CFOs (Lee 2012). Discontinued operations often lead to misclassifications that occur when firms lump operating, investing, and financing cash flows from discontinued operations into a single line-item-often included in the operating section of the SCF, which distorts a firm's cash flows. Further, SFAS No. 95 and SFAS No. 144 have historically contributed to cash flow misunderstandings by presenting different interpretations of requirements and different options for reporting cash flows from discontinued operations.

The change in earnings-cash flow ratio is likely associated with CFRs because CFO becomes an important component in setting CEO cash compensation when the quality of earnings relative to the quality of CFO as a 
measure of performance is low (Nwaeze et al., 2006). Large book-tax differences can often draw IRS scrutiny (Mills, 1998), and, as a result, firms may be more likely to understate CFO to de-emphasize the significance of the amount of cash that is attributable to their daily operations. A firm with more agency conflicts (proxied for by free cash flow) can provide managers with more opportunity to inflate CFO because managers have varying incentives to report higher CFO (Lee, 2012), which can lead to more CFRs. We analyze total accruals because a wide gap between earnings and CFO is often a "red flag" of potential earnings management (Wild, Subramanyam, \& Hasley, 2004), which can result in a CFR.

Dividends can be associated with CFRs because SFAS 150, Accounting for Certain Financial Instruments with Characteristics of both Liabilities and Equity, has historically led to classification issues with respect to dividends (Nurnberg, 2006) for firms that issue mandatorily redeemable preferred stock. Analysts' cash flow forecasts are important for investors of firms where accounting, operating, and financing characteristics suggest that cash flows are useful in interpreting earnings and assisting in forecasting the firm's future performance (Defond \& Hung, 2003). Further, Lee (2012) finds that firms with CFRs are more likely to have at least one analyst cash flow forecast during the fiscal year. Prior research has found that bigger audit firms (i.e., Big $\mathrm{N}$ firms) have better financial resources, research facilities, superior technology, and more talented employees to undertake large company audits than smaller audit firms but also that they are more likely to be sued (Lys \& Watts, 1994; Deis Jr \& Giroux, 1992; Lennox, 1999), which can result in more conservative cash flow reporting.

\subsection{Market Reactions to Cash Flow Restatements}

We then assess the market's reactions to overstated versus understated CFR disclosures. We examine various windows surrounding the CFR disclosure, allowing for any early news leakage that may occur on day -1 and any news delay that may occur as a result of a restatement announcement after the close of trading on day 0. (Note 4) These windows are $(-1,1)$ and $(0,2)$. We also examine the abnormal return on the actual day of the CFR announcement $(0,0)$. We use a Fama-French market-adjusted returns model based on a value-weighted market index to estimate abnormal returns. The model subtracts the CRSP market index return from a company's daily return to obtain the market-adjusted abnormal return for each day and company. The daily abnormal returns are summed to calculate the cumulative abnormal return for a given event window. Restatements are perceived as bad news, regardless of whether firms overstate or understate cash flows. An understatement of cash flows can be perceived as bad news because this type of restatement is a possible indication of poor financial reporting and/or possible internal control issues.

\section{Data and Empirical Results}

\subsection{Data Sample Selection}

We identified firms that restated their SCF in the Audit Analytics Inc. database. The Audit Analytics restatement data set covers all SEC registrants who have disclosed CFRs from 1999 to 2013. The initial study population comprised 607 firm-year observations and 332 unique firms. After eliminating CFRs with concurrent earnings or balance sheet restatements, our sample decreased to 275 firm-year observations (168 unique firms). Our sample size also decreased by 50 firm-year observations ( 30 unique firms) for firms that were missing data required in CRSP. If a firm disclosed restatements for multiple years, we used each year restated.

After accounting for these data requirements, Table 1 indicates that our final sample consisted of 225 firm-year observations and 138 unique firms that disclosed at least one CFR over our sample period for 143 unique disclosure dates. We also present the sample distribution between CFR firms who overstate versus understate operating and total cash flows. Our final sample size for firms which overstate (understate) CFOs was 93 (108) firm-year observations consisting of 76 (68) unique firms and 77 (70) unique disclosure dates. The sample sizes for firms who overstate and understate did not include 24 observations that had no change to TCFs. Lastly, our final sample size for firms that had changes in TCFs was 139 firm-year observations consisting of 97 unique firms and 101 unique disclosure dates. 
Table 1. Sample Selection Criteria and Distribution

\begin{tabular}{|c|c|c|c|c|}
\hline & $\begin{array}{lr}\text { Cash } & \text { Flow } \\
\text { Restatement Sample }\end{array}$ & $\begin{array}{l}\text { Cash Flow } \\
\text { Overstatement } \\
\text { Sample }\end{array}$ & $\begin{array}{l}\text { Cash Flow } \\
\text { Understatement } \\
\text { Sample }\end{array}$ & $\begin{array}{l}\text { Changes in Total } \\
\text { Cash Flows } \\
\text { Sample }\end{array}$ \\
\hline Cash Flow Restatement Sample & $\begin{array}{l}\text { No. of Firm-Years / } \\
\text { No. of Firms }\end{array}$ & $\begin{array}{l}\text { No. of } \\
\text { Firm-Years }\end{array}$ & $\begin{array}{ll}\text { No. } & \text { of } \\
\text { Firm-Years }\end{array}$ & $\begin{array}{l}\text { No. } \\
\text { Firm-Years }\end{array}$ \\
\hline $\begin{array}{l}\text { Firms with cash flow restatements in } \\
\text { Audit Analytics from 1999-2013 } \\
\text { (SFAS No. } 95 \text { classification errors) }\end{array}$ & $607 / 332$ & $242 / 171$ & $253 / 163$ & $369 / 233$ \\
\hline $\begin{array}{l}\text { Cash flow restatements without } \\
\text { concurrent earnings restatements } \\
\text { which are reported in disclosures } \\
\text { other than } 10-\mathrm{K} \text { (e.g. 10-Q, 10-Q/A, } \\
\text { 8-K, etc.) or balance sheet } \\
\text { irregularities }\end{array}$ & $275 / 168$ & $117 / 93$ & $129 / 81$ & $165 / 116$ \\
\hline $\begin{array}{l}\text { Firms that } t \text { have a match on CRSP } \\
\text { based on PERMNO code, without } \\
\text { missing data required in CRSP }\end{array}$ & $225 / 138$ & $93 / 76$ & $108 / 68$ & $139 / 97$ \\
\hline $\begin{array}{l}\text { Final Number of Firm-Year } \\
\text { Observations/Unique } \\
\text { Firms/Unique Disclosure Dates }\end{array}$ & $225 / 138 / 143$ & $93 / 76 / 77$ & $108 / 68 / 70$ & 139 / $97 / 101$ \\
\hline
\end{tabular}

3.2 Industry and Year Distributions

In Table 2, we examine the yearly distribution of CFRs. We found that a large percentage (approximately $34 \%$ ) of years restated occurred in 2002 through 2006. This is consistent with the rise in CFRs noted by the SEC prior to the SEC allowance period in 2006. The allowance period allowed firms to restate their previous year's cash flow statements without penalty. The decrease in CFRs in 2005 is also consistent with firms anticipating this one-time allowance and increasing their focus on the correct classification of items within the SCF during the period 2005-2006. In addition, we found that firms that reported a change in TCF comprised $62 \%$ of our full sample. Firms that reported no change in total CFR comprised $38 \%$ of total observations. These are most likely firms that primarily restated due to classification shifting (i.e., misclassification). Firms that reported an overstatement (understatement) in TCFs comprised $29.33 \%$ (32.44\%) of our sample. Lastly, firms that reported overstated (understated) CFOs comprised $41.33 \%(48.00 \%)$ of our sample. This distribution of the types of restatements (i.e., overstated or understated) further corroborates the need to examine understated CFRs, which have generally been overlooked in the literature. We also note that $10.67 \%$ of the sample (24 observations) had no change in CFO and were excluded from this subsample, where 201 firm-year observations remained. 
Table 2. Yearly Distribution

\begin{tabular}{llllllll}
\hline & \multicolumn{3}{c}{ Total CFR Surprise } & \multicolumn{3}{l}{ CFR Surprise -Operating } \\
& Total & \multicolumn{2}{l}{ original minus restated } & \multicolumn{3}{l}{ original minus restated } \\
Year & $\%$ & No & over & under & No & over & under \\
& & Change & statement & statement & Change & statement & statement \\
\hline $\mathbf{1 9 9 9}$ & 1 & 1 & 0 & 0 & 0 & 1 & 0 \\
$\mathbf{2 0 0 0}$ & 1 & 1 & 0 & 0 & 0 & 1 & 0 \\
$\mathbf{2 0 0 1}$ & 8 & 4 & 3 & 1 & 0 & 0 & 8 \\
$\mathbf{2 0 0 2}$ & 14 & 6 & 4 & 4 & 1 & 4 & 9 \\
$\mathbf{2 0 0 3}$ & 29 & 8 & 9 & 12 & 2 & 6 & 21 \\
$\mathbf{2 0 0 4}$ & 25 & 6 & 6 & 13 & 1 & 13 & 11 \\
$\mathbf{2 0 0 5}$ & 19 & 5 & 4 & 10 & 1 & 9 & 9 \\
$\mathbf{2 0 0 6}$ & 20 & 6 & 9 & 5 & 1 & 13 & 6 \\
$\mathbf{2 0 0 7}$ & 16 & 6 & 3 & 7 & 2 & 6 & 8 \\
$\mathbf{2 0 0 8}$ & 20 & 10 & 4 & 6 & 4 & 6 & 10 \\
$\mathbf{2 0 0 9}$ & 19 & 8 & 6 & 5 & 4 & 8 & 7 \\
$\mathbf{2 0 1 0}$ & 14 & 4 & 5 & 5 & 0 & 7 & 7 \\
$\mathbf{2 0 1 1}$ & 17 & 7 & 7 & 3 & 3 & 8 & 6 \\
$\mathbf{2 0 1 2}$ & 13 & 8 & 3 & 2 & 3 & 7 & 3 \\
$\mathbf{2 0 1 3}$ & 9 & 6 & 3 & 0 & 2 & 4 & 3 \\
& 225 & 86 & 66 & 73 & 24 & 93 & 108 \\
Total & $100.00 \%$ & $38.22 \%$ & $29.33 \%$ & $32.44 \%$ & $10.67 \%$ & $41.33 \%$ & $48.00 \%$ \\
\hline
\end{tabular}

\subsection{Summary Statistics for Firm Characteristics}

In Panel A of Table 3, we present the summary statistics for the firm characteristics between firms that reported an understatement versus overstatement in TCFs. Among firms that reported an understatement in TCFs, we found that the following firm characteristics were significantly different from zero: average total assets (ATA), total debt (DEBT), return on asset (ROA), change in earnings relative to CFOs ( $|\Delta \mathbf{E} / \triangle \mathbf{C F O}|)$, firm size (SIZE), market-to-book ratio (MB), book-tax difference (BTD), firm distress (DISTRESS), dividends (DIV), Big N auditor (BIGN), CFO forecasts (IBEScfo), and the number of business segments (NUMSEG). For firms that reported an overstatement in TCFs, we found similar significance levels with the exception of ROA, free cash flow (FCF), and meet-or-beat earnings forecast (MBE). When compared to firms that understated TCF, we found that firms that overstated TCF are more complex when measured by the number of segments. Otherwise, the firm characteristics are statistically the same between the over- and understated firms.

Panel B of Table 3 reports the summary statistics for the firm characteristics between firms that reported an understatement in CFO compared to those firms that reported an overstatement in CFO. Among firms that reported an understatement in CFO, we found that the following firm characteristics are statistically significant at the $1 \%$ level: average total assets (ATA), current ratio (CR), total debt (DEBT), change in earnings to CFOs $(\mid \Delta \mathrm{E} / \Delta \mathrm{CFO}$ ), firm size (SIZE), book-tax difference (BTD), firm distress (DISTRESS), dividends (DIV), Big N auditor (BIGN), number of business segments (NUMSEG), and the change in the amount of restated CFO (OPG_CHCF). For firms that reported an overstatement in CFO, we found similar significance levels except for meeting or beating earnings (MBE) and CFO forecasts (IBEScfo), which are significant at the $1 \%$ level. We also found that firms with understated CFO had significantly lower incidence of CFO forecasts (IBEScfo) and were less complex (NUMSEG) compared to firms with overstated CFO.

\subsection{Market Reactions to Over/Understated Cash Flow Restatements}

Table 4 presents the cumulative abnormal return and its statistical significance for the three-day event windows of $(-1,1)$ and $(0,2)$ surrounding the CFR announcement as well as on the day of the announcement $(0,0)$. We chose 
these event windows to be consistent with event windows employed in prior research related to restatements (e.g., Palmrose, Richardson, and Scholz 2004; and Hollie, Nicholls and Zhao 2011). We present the post-announcement drift results using $(2,180)$ and $(2,360)$ event windows. In Panel A of Table 4 , we examine the market reaction to CFR surprises from CFOs. We found a significantly negative short-term market reaction (-0.0134) to CFRs that report an understatement of CFO in the $(-1,1)$ window $(p=0.0079)$. This negative market reaction persists on the announcement day $(0,0)$ as well as in the $(0,2)$ event window.

However, when analyzing the post-announcement drift results, we found that the market reaction becomes positive and marginally significant for firms that overstated CFO. Therefore, it appears that the immediate negative market reaction is an overreaction, and the market return reversal suggests that, in time, investors revise their expectations upward when firms understate CFO. On the other hand, we found that there was no significant market reaction to CFRs that reported an overstatement of CFO during both the $(-1,1)$ and $(0,2)$ event windows. The post-announcement drift results indicate that investors only revise expectations slightly upward over the next 180 days $(p=0.0818)$. We did not find significance on an even longer post-announcement drift term to 360 days for overstated firms. When comparing understatements to overstatements, we found that, on the announcement date $(0$, 0 ), the market reaction to CFO overstatements was significantly greater than the reaction to CFO understatements ( $p$ $=0.0149$ ).

Table 3. Summary Statistics for Firms with Overstated versus Understated Cash Flow Restatements Panel A: Under- and Over- Statements in Total Cash Flows

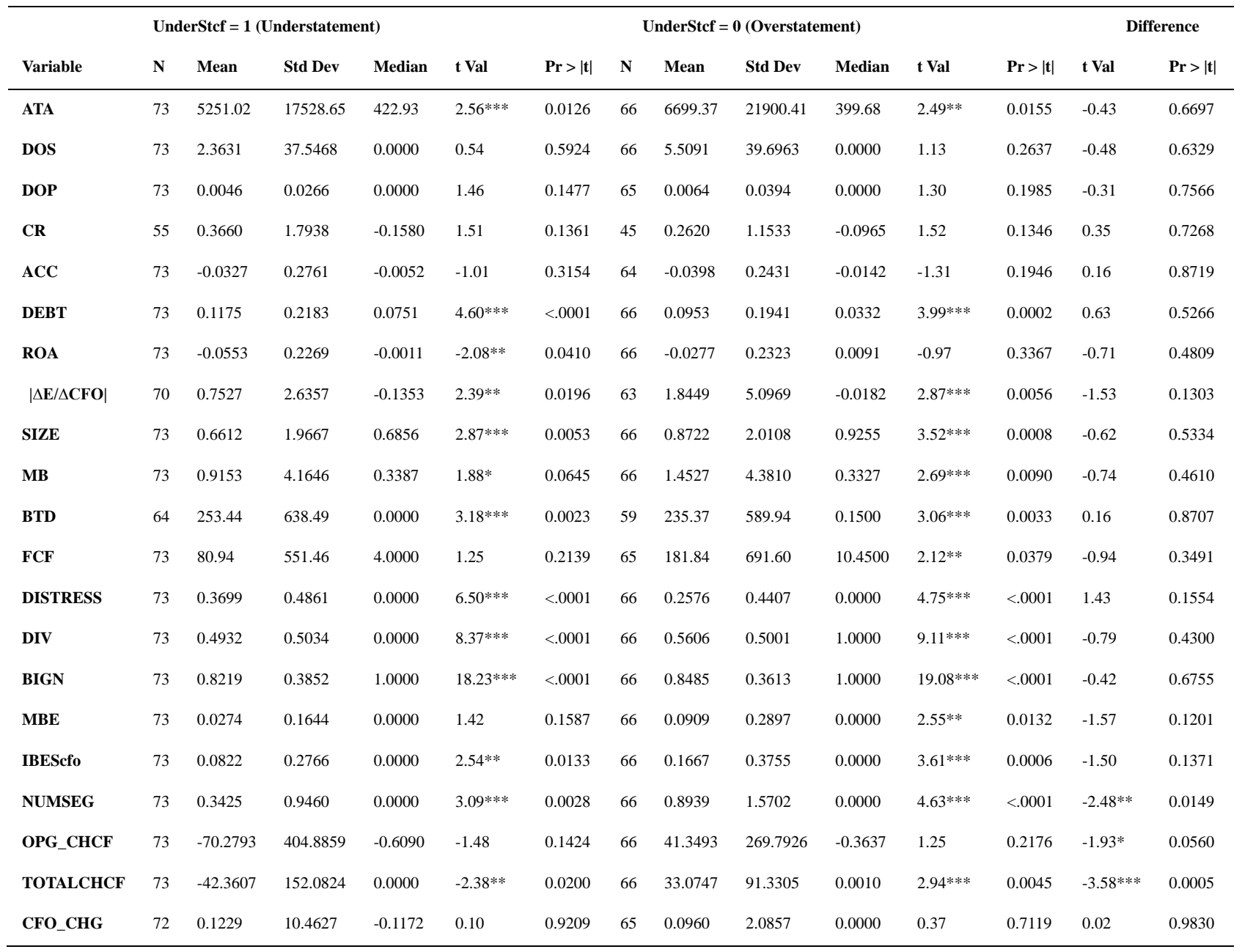

Significant at different levels: $* \mathrm{p}<0.1, * * \mathrm{p}<0.05, * * * \mathrm{p}<0.01$. 
Table 3 (cont'd). Summary Statistics for Firms with Overstated versus Understated Cash Flow Restatements Panel B: Under- and Over- Statements in Cash Flows from Operating Activities

\begin{tabular}{|c|c|c|c|c|c|c|c|c|c|c|c|c|c|c|}
\hline \multirow[b]{2}{*}{ Variable } & \multicolumn{6}{|c|}{ UnderSopg = 1 (Understatement $)$} & \multicolumn{6}{|c|}{ UnderSopg $=0$ (Overstatement $)$} & \multicolumn{2}{|c|}{ Difference } \\
\hline & $\mathbf{N}$ & Mean & Std Dev & Median & t Val & $\operatorname{Pr}>|t|$ & $\mathbf{N}$ & Mean & Std Dev & Median & t Val & $\operatorname{Pr}>|t|$ & t Val & $\operatorname{Pr}>\mid t$ \\
\hline ATA & 108 & 5817.67 & 15973 & 395.44 & $3.78^{* * *}$ & 0.0003 & 93 & 9535.63 & 25202.32 & 394.17 & $3.65^{* * *}$ & 0.0004 & -1.23 & 0.2220 \\
\hline DOS & 108 & 3.9176 & 37.76 & 0.0000 & 1.08 & 0.2835 & 93 & -1.3799 & 14.4413 & 0.0000 & -0.92 & 0.3592 & 1.35 & 0.1799 \\
\hline DOP & 107 & 0.0063 & 0.0349 & 0.0000 & $1.86^{*}$ & 0.0661 & 93 & 0.0001 & 0.0091 & 0.0000 & 0.09 & 0.9281 & $1.76^{*}$ & 0.0802 \\
\hline CR & 79 & 0.3979 & 1.7297 & -0.1390 & $2.04 * *$ & 0.0443 & 66 & 0.2880 & 1.2326 & -0.1073 & $1.90^{*}$ & 0.0621 & 0.45 & 0.6568 \\
\hline ACC & 106 & -0.0344 & 0.2509 & -0.0054 & -1.41 & 0.1607 & 92 & 0.0034 & 0.2522 & 0.0011 & 0.13 & 0.8970 & -1.06 & 0.2926 \\
\hline DEBT & 108 & 0.1356 & 0.2179 & 0.1013 & $6.46^{* * *}$ & $<.0001$ & 93 & 0.1082 & 0.2066 & 0.0371 & $5.05^{* * *}$ & $<.0001$ & 0.91 & 0.3631 \\
\hline ROA & 108 & -0.0394 & 0.1999 & 0.0012 & $-2.05 * *$ & 0.0430 & 93 & -0.0280 & 0.1983 & 0.0024 & -1.36 & 0.1767 & -0.40 & 0.6860 \\
\hline$|\Delta \mathbf{E} / \Delta \mathbf{C F O}|$ & 106 & 1.8196 & 5.6130 & -0.1154 & $3.34 * * *$ & 0.0012 & 88 & 1.2687 & 3.9504 & -0.1329 & $3.01 * * *$ & 0.0034 & 0.80 & 0.4250 \\
\hline MB & 108 & 1.0418 & 4.3594 & 0.0862 & $2.48 * *$ & 0.0146 & 93 & 0.9430 & 3.6273 & 0.1937 & $2.51 * *$ & 0.0139 & 0.18 & 0.8609 \\
\hline BTD & 95 & 261.85 & 603.13 & 0.0000 & $4.23^{* * *}$ & $<.0001$ & 84 & 257.98 & 677.19 & 0.1700 & $3.49^{* * *}$ & 0.0008 & 0.04 & 0.9680 \\
\hline FCF & 107 & 130.82 & 519.58 & 9.6600 & $2.60 * *$ & 0.0105 & 92 & 147.67 & 816.11 & 6.4000 & $1.74 *$ & 0.0860 & -0.17 & 0.8648 \\
\hline DISTRESS & 108 & 0.3241 & 0.4702 & 0.0000 & $7.16^{* * * *}$ & $<.0001$ & 93 & 0.3656 & 0.4842 & 0.0000 & $7.28 * * *$ & $<.0001$ & -0.61 & 0.5398 \\
\hline DIV & 108 & 0.5093 & 0.5022 & 1.0000 & $10.54 * * *$ & $<.0001$ & 93 & 0.4946 & 0.5027 & 0.0000 & $9.49 * * *$ & $<.0001$ & 0.21 & 0.8371 \\
\hline BIGN & 108 & 0.8611 & 0.3474 & 1.0000 & $25.76 * * *$ & $<.0001$ & 93 & 0.7957 & 0.4054 & 1.0000 & $18.93 * * *$ & $<.0001$ & 1.22 & 0.2248 \\
\hline MBE & 108 & 0.0278 & 0.1651 & 0.0000 & $1.75^{*}$ & 0.0833 & 93 & 0.0860 & 0.2819 & 0.0000 & $2.94 * *$ & 0.0041 & $-1.75^{*}$ & 0.0822 \\
\hline IBEScfo & 108 & 0.0556 & 0.2301 & 0.0000 & $2.51 * *$ & 0.0136 & 93 & 0.2473 & 0.4338 & 0.0000 & $5.50 * * *$ & $<.0001$ & $-3.82 * * *$ & 0.0002 \\
\hline NUMSEG & 108 & 0.3981 & 1.1102 & 0.0000 & $3.73^{* * *}$ & 0.0003 & 93 & 0.9140 & 1.5649 & 0.0000 & $5.63^{* * *}$ & $<.0001$ & $-2.66^{* *}$ & 0.0087 \\
\hline TOTALCHCF & 108 & -21.10 & 131.85 & 0.0000 & $-1.66^{*}$ & 0.0992 & 93 & 12.0262 & 67.6825 & 0.0000 & $1.71^{*}$ & 0.0900 & $-2.28 * *$ & 0.0236 \\
\hline CFO_CHG & 107 & 0.5065 & 8.7565 & -0.0593 & 0.60 & 0.5509 & 91 & 1.2742 & 12.4217 & -0.0001 & 0.98 & 0.3304 & -0.49 & 0.6218 \\
\hline
\end{tabular}

Significant at different levels: $* \mathrm{p}<0.1, * * \mathrm{p}<0.05, * * * \mathrm{p}<0.01$.

In Panel B of Table 4, we analyze the market reactions to CFR surprises of TCFs. When examining firms that report an understatement of TCFs, we found a significantly negative market reaction of -0.0162 for the $(-1,1)$ window consistent with the negative reaction to TCF understatements $(p=0.0052)$. This result holds when examining the $(0$, 2 ) event window ( $p=0.0063)$, although it is insignificant on the announcement date $(0,0)(p=0.8018)$. We found a return reversal of 0.1269 that is significant at the 5\% level $(p=0.0125)$ when using a post-announcement drift window of $(2,180)$. On the contrary, we found that there was no immediate market reaction to CFRs with overstated TCF on either the three-day windows of $(-1,1)$ or $(0,2)$ or the announcement date $(0,0)$. When analyzing long-term windows, we found that there was a significantly positive return reversal over the full year after the CFR announcement using the $(2,360)$ window $(p=0.0092)$. The negative market reaction at the $(-1,1)$ window is marginally significant to understated TCFs relative to overstated TCFs $(\mathrm{t}=-1.83, p=0.0705)$. 
Table 4. Cumulative Abnormal Returns (CARs) for Event Windows

Surrounding Cash Flow Restatement Disclosures

Panel A: CFR Surprise of Operating Cash Flows

\begin{tabular}{lllllll}
\hline & & $\mathbf{( - 1 , 1 )}$ & $\mathbf{( 0 , 0 )}$ & $\mathbf{( 0 , 2 )}$ & Drift (2, 180) & Drift (2, 360) \\
\hline Understatement & $\mathbf{N}$ & 69 & 68 & 68 & 67 & 68 \\
& Mean & -0.0134 & -0.0062 & -0.0104 & 0.0822 & 0.1117 \\
& $\mathbf{t}$-value & $-2.74^{*}$ & $-1.81^{*}$ & $-2.11^{* *}$ & $1.75^{*}$ & $1.78^{*}$ \\
& $\mathbf{p}$-value & 0.0079 & 0.0741 & 0.0383 & 0.0855 & 0.0801 \\
Overstatement & $\mathbf{N}$ & 72 & 73 & 73 & 74 & 73 \\
& Mean & -0.0052 & 0.0055 & -0.0006 & 0.0780 & 0.0973 \\
& $\mathbf{t}$-value & -0.85 & $1.67^{*}$ & -0.13 & $1.76^{*}$ & 1.49 \\
& $\mathbf{p}$-value & 0.3963 & 0.0990 & 0.8948 & 0.0818 & 0.1419 \\
& & & & & & \\
Difference & $\mathbf{t}$-value & -1.05 & $-2.47^{* *}$ & -1.47 & 0.06 & 0.16 \\
& $\mathbf{p}$-value & 0.2934 & 0.0149 & 0.1437 & 0.9483 & 0.8744 \\
\hline
\end{tabular}

Significant at different levels: $* \mathrm{p}<0.1, * * \mathrm{p}<0.05, * * * \mathrm{p}<0.01$

Panel B: CFR Surprise of Total Cash Flows

\begin{tabular}{lllllll}
\hline & & $\mathbf{( - 1 , 1 )}$ & $\mathbf{( 0 , 0 )}$ & $\mathbf{( 0 , 2 )}$ & Drift (2, 180) & Drift (2, 360) \\
\hline Understatement & $\mathbf{N}$ & 55 & 54 & 55 & 56 & 55 \\
& Mean & -0.0162 & 0.0009 & -0.0143 & 0.1269 & 0.1083 \\
& $\mathbf{t}$-value & $-2.91^{* *}$ & 0.25 & $-2.85^{* *}$ & $2.58^{* *}$ & 1.38 \\
& $\mathbf{p}$-value & 0.0052 & 0.8018 & 0.0063 & 0.0125 & 0.1734 \\
Overstatement & & & & & \\
& $\mathbf{N}$ & 53 & 55 & 54 & 53 & 54 \\
& Mean & -0.0021 & 0.0028 & -0.0037 & 0.0752 & 0.1725 \\
& t-value & -0.39 & 0.94 & -0.87 & 1.53 & $2.70^{* *}$ \\
& $\mathbf{p}$-value & 0.6979 & 0.3504 & 0.3889 & 0.1319 & 0.0092 \\
& & & & & & -0.63 \\
& t-value & $-1.83^{*}$ & -0.40 & -1.61 & 0.74 & 0.5269 \\
\hline
\end{tabular}

Significant at different levels: $* \mathrm{p}<0.1, * * \mathrm{p}<0.05, * * * \mathrm{p}<0.01$.

\subsection{Multivariate Analysis of Market Reactions to CFRs}

In Table 5, we examine the market reaction to over/understatements of operating, investing, and financing statement of cash flow components. We defined UnderSopg as equal to one if the firm reported understated CFO and zero if the firm reported overstated CFO. We defined UnderSinv as equal to one if the firm reported understated investing cash flows and zero if the firm reported overstated investing cash flows. UnderSfin was measured in the same manner, but it is not included in the model because it serves as the reference group. When examining the short-term reaction, we found a significantly negative reaction to understated CFOs in the $(-1,1)$ event window (UnderSopg coefficient $=-0.0146$ ). This result implies that compared to understated financing cash flows, the market reaction to understated CFOs is significantly more negative. These results are consistent when examining the CFR announcement date $(0,0)$ and the $(0$, 2) event window. 
Intuition would lead one to expect a positive market reaction when a firm upwardly restates CFOs. However, we found the opposite. One plausible explanation is that the market sees this evidence as bad news because it is a financial statement error. Another plausible explanation is that we generally find that when CFO is understated, investing cash flows is overstated. This downward revision of investing cash flows could indicate something about expected future returns on investments. Another explanation is that the market overreacted, as it sometimes does with earnings restatements. We performed additional analysis to determine whether there was a post-announcement drift. We found that the market did positively adjust itself for the initial negative market reaction in the subsequent six to twelve-month window, which is consistent with a post-announcement drift. For the $(2,180)$ event window, the coefficient increased to $0.0974(p=0.0332)$, and for the $(2,360)$ window, the coefficient increased to $0.2053(p=0.0022)$. These results provide additional evidence that investors correct for their initial negative reaction to CFO understatements over the following twelve months after a CFR disclosure. We found only a marginal positive reaction to understated investing cash flows on the announcement date $(0,0)$ (UnderSinv coefficient $=0.0064$ ). Lastly, we found a significantly positive coefficient on the interaction of operating and investing cash flows during the $(0,2)$ window (UnderSopg*UnderSinv coefficient $=0.0252, p=0.0463$ ). This result indicates that when a CFR includes both an understatement of CFOs and an understatement of investing cash flows, there is an incrementally positive reaction compared to CFRs with understated financing cash flows.

Table 5. Multivariate Analysis - Cumulative Abnormal Returns (CARs)

\begin{tabular}{lllllll}
\hline Dependent Variable & & $\mathbf{( - 1 , 1 )}$ & $\mathbf{( 0 , 0 )}$ & $\mathbf{( 0 , 2 )}$ & $\mathbf{( 2 , 1 8 0 )}$ & $\mathbf{( 2 , 3 6 0 )}$ \\
\hline UnderSopg & Coefficient & -0.0146 & -0.0057 & -0.0101 & 0.0974 & 0.2053 \\
& t-value & $-3.00^{* *}$ & $-1.72^{*}$ & $-2.30^{* *}$ & $2.15^{* *}$ & $3.12^{* *}$ \\
& p-value & 0.0032 & 0.0866 & 0.0226 & 0.0332 & 0.0022 \\
UnderSinv & & & & & & \\
& Coefficient & -0.0056 & 0.0064 & -0.0055 & 0.0940 & 0.1316 \\
& t-value & -1.06 & $1.78^{*}$ & -1.16 & $1.97 *$ & $1.87^{*}$ \\
& p-value & 0.2908 & 0.0767 & 0.2462 & 0.0508 & 0.0635 \\
UnderSopg*UnderSinv & Coefficient & 0.0242 & 0.0043 & 0.0252 & 0.0650 & -0.1121 \\
& $\mathrm{t}$-value & $1.67^{*}$ & 0.44 & $2.01^{* *}$ & 0.51 & -0.60 \\
& $\mathrm{p}$-value & 0.0979 & 0.6611 & 0.0463 & 0.6133 & 0.5516 \\
No. of Observations & & & & & & 153 \\
R-Square & & 155 & 155 & 154 & 153 & 0.0918 \\
Adj. R-Square & & 0.0630 & 0.041 & 0.0471 & 0.0848 & 0.0737 \\
F Value & & 0.0445 & 0.0221 & 0.0282 & 0.0665 & 5.05 \\
Pr > F & & 3.41 & 2.17 & 2.49 & 4.64 & 0.0023 \\
\hline Sign & & 0.0192 & 0.0944 & 0.0625 & 0.004 & \\
\hline
\end{tabular}

Significant at different levels: $* \mathrm{p}<0.1, * * \mathrm{p}<0.05, * * * \mathrm{p}<0.01$.

\section{Summary and Conclusions}

Surprisingly, about half of all CFRs studied involved an understatement of CFOs. Because understated CFR firms have essentially been ignored in prior research, we examined the firm characteristics and market implications for both firms that overstate and those that understate operating and TCFs. We found that there was a significantly negative initial market reaction to understatements of CFOs. However, this immediate reaction is incomplete as investors appear to reverse their valuations upward over the next six to twelve months. On the contrary, we did not find that investors reacted significantly to CFO overstatements. We then found evidence that the market has a significantly negative reaction to the understatement of TCFs. On a less significant basis, we found that long-term, investors revise their expectations upward and reverse their initial negative reaction that is consistent with a slight post-announcement drift. Our results indicate that understated CFRs are important to investors and may provide information for the firm valuation process. 
One limitation is that the results are subject to low power because of our strict "pure" CFRs sample selection criteria and final sample size. This design choice is a tradeoff to ensuring that we reduced confounding effects as much as possible in our market reaction analysis related to earnings restatements and balance sheet adjustments, both of which we know can have significantly negative market reactions.

\section{References}

Alfonso, E., Hollie, D., \& Yu, S. (2018). Determinants and economic consequences of cash flow restatements. Journal of Accounting \& Public Policy, 31(1) 82-97. https://doi.org/10.1016/j.jaccpubpol.2018.01.001.

Ali, A. (1994). The Incremental Information Content of Earnings, Working Capital from Operations, and Cash Flows. Journal of Accounting Research, 32(1), 61-74. https://doi.org/10.2307/2491387.

AICPA. (2006). Center for Public Company Audit Firms Alert No. 90, SEC Staff Position Regarding Changes to the Statement of Cash Flows Relating to Discontinued Operations.

AICPA. (2006). Center for Public Company Audit Firms Alert No. 98, Update to SEC Staff Position Regarding Changes to the Statement of Cash Flows Relating to Discontinued Operations.

Audit Analytics Trend Reports. (2014). Financial Restatements 2013 - A 13 Year Comparison May 13, 2014. New York, NY: Alacra Store. Retrieved Apr 30, 2019 from <http://www.alacrastore.com/storecontent/Audit-Analytics-Trend-Reports/Financial-Restatements-2013-A-13Year-Comparison-2033-35>.

Ball, R., Gerakos, J., Linnainmaa, J., \& Nikolaev, V. (2016). Accruals, cash flows, and operating profitability in the cross section of stock returns. Journal of Financial Economics, 121(1), 28-45. https://doi.org/10.1016/j.jfineco.2016.03.002.

Barth, M., Cram, D., \& Nelson, K. (2001). Accruals and the Prediction of Future Cash Flows. The Accounting Review, 76, 27-58. https://doi.org/10.2308/accr.2001.76.1.27.

Barth, M., Clinch, G., \& Israeli, D. (2016). What do accruals tell us about future cash flows? Review of Accounting Studies, 2l(3), 768-807. https://doi.org/10.1007/s11142-016-9360-4.

Bowen, R., Burgstahler, D., \& Daley, L. (1987). The incremental information content of accrual versus cash flows. The Accounting Review, 62, 723-74.

Call, A. (2008). Analysts' cash flow forecasts and the predictive ability and pricing of operating cash flows. Working paper, University of Georgia. https://dx.doi.org/10.2139/ssrn.1362177.

Chen, H., Chen, Z., Dhaliwal, D., \& Huang, Y. (2017). Accounting Restatements and Corporate Cash Policy. Journal of Accounting, Auditing \& Finance. https://doi.org/10.1177/0148558X17732654.

Cheng, C.S.A. \& Hollie, D. (2008). Do Core and Non-core Cash Flows from Operations Persist Differentially in Predicting Future Cash Flows? Review of Quantitative Finance and Accounting, 31, 29-53. https://doi.org/10.1007/s11156-007-0062-7

Dechow, P. (1994). Accounting earnings and cash flows as measures of firm performance: The role of accounting accruals. Journal of Accounting and Economics, 18(1), 3-42. https://doi.org/10.1016/0165-4101(94)90016-7.

DeFond, M., \& Hung, M. (2003). An Empirical Analysis of Analysts' Cash Flow Forecasts. Journal of Accounting and Economics, 35(1), 73-100. https://doi.org/10.1016/S0165-4101(02)00098-8.

Deis Jr., Donald R., \& Giroux, Gary A. (1992). Determinant of Audit Quality in the Public Sector. The Accounting Review, 67(3).

Drakopoulou, V. (2018). Are the Recent Restatements of Financial Institutions 10K's due to the Perceived Earning Volatility Caused by SFAS 161? Accounting and Finance Research, 7(4) https://doi.org/10.5430/afr.v7n4p122.

FASB. (1978). Statement of Financial Accounting Concepts No. 1: Objectives of Financial Reporting by Business Enterprises. Stamford, Conn.: FASB.

FASB. (1987). Statement of Financial Accounting Standards No. 95, Statement of Cash Flows, Stamford, CT.

FASB. (2001). Statement of Financial Accounting Standards No. 144, Accounting for Impairment or Disposal of Long-Lived Assets, Stamford, CT.

FASB. (2003). Statement No. 150, Accounting for Certain Financial Instruments with Characteristics of both Liabilities and Equity. Norwalk Conn. 
Hairston, S., Yu, J., \& Liu, Z. (2019). Does Manager Ability Influence Prospectus Earnings Quality and IPO Underpricing? Accounting and Finance Research, 8(1). https://doi.org/10.5430/afr.v8n1p1.

Hollie, D., Nicholls, C., \& Zhao, Q. (2011). Effects of Cash Flow Statement Reclassifications Pursuant to the SEC's One-time Allowance. Journal of Accounting \& Public Policy, 30, 570-588. https://doi.org/10.1016/j.jaccpubpol.2011.04.003.

Lail, B., \& Martin, G. (2017). Are Entrenched Managers' Accounting Choices More Predictive of Future Cash Flows? Journal of Business, Finance \& Accounting, 44(5-6), 593-610. https://doi.org/10.1111/jbfa.12247.

Lee, L. (2012). Incentives to Inflate Reported Cash from Operations Using Classification and Timing. The Accounting Review, 87, 1-33. https://doi.org/10.2308/accr-10156.

Lennox, C. (1999). Audit Quality and Auditor Size: An Evaluation of Reputation and Deep Pockets Hypothesis. Journal of Business Finance \& Accounting, 26(7-8), 779-805. https://doi.org/10.1111/1468-5957.00275.

Levine, J. (2005). Speech by SEC staff: Remarks before the 2005 thirty-third AICPA National Conference on Current SEC and PCAOB Developments. Securities Exchange Commission www.sec.gov/news/speech/spch120605jl.htm

Luo, M. (2008). Unusual Operating Cash Flows and Stock Returns. Journal of Accounting, and Public Policy, 27, 420-429. https://doi.org/10.1016/j.jaccpubpol.2008.07.004.

Lys, T., \& Watts, R. (1994). Lawsuits Against Auditors. Journal of Accounting Research, 32 Supplement, 65-93. https://doi.org/10.2307/2491440.

Mills, L. (1998). Book-tax Differences and Internal Revenue Service adjustments. Journal of Accounting Research, 36(2), 343-356. https://doi.org/10.2307/2491481.

Mulford, C.W., \& Comiskey, E. (2005). Creative Cash Flow Reporting: Uncovering Sustainable Financial Performance. New York: John Wiley \& Sons, Inc.

Mulford, C.W. \& Martins, M. (2004). Cash-flow Reporting Practices for Customer-related Notes Receivable. Georgia Tech Financial Analysis Lab.

Mulford, C.W. \& Martins, M. (2005a). Cash-flow Reporting Practices for Customer-related Notes Receivable: An Update. Georgia Tech Financial Analysis Lab.

Mulford, C.W. \& Martins, M. (2005b). Customer-related Notes Receivable and Reclassified Cash Flow Provided by Operating Activities. Georgia Tech Financial Analysis Lab.

Nurnberg, H. (1983). Issues in Funds Statement Presentation. The Accounting Review, 58, 799-812.

Nurnberg, H. \& Largay, J. (1996). More Concerns over Cash Flow Reporting under FASB Statement No. Accounting Horizons, 10, 123-136.

Nurnberg, H. (2006). Perspectives on the Cash Flow Statement under FASB Statement No. 95. Columbia Business School: Center for excellence in accounting and security analysis (Occasional paper series). New York, NY: Columbia Business School.

Nwaeze, T., Yang, S., \& Yin, Q. (2006). Accounting information and CEO compensation: The Role of Cash Flow from Operations in the Presence of Earnings. Contemporary Accounting Research, 23(1), 227-265. https://doi.org/10.1506/BUQJ-8KUQ-X2TF-K7T4.

Palmrose, Z, Richardson, V. J., \& Scholz, S. (2004). Determinants of Market Reactions to Restatement Announcements. Journal of Accounting and Economics, 37, 59-89. https://doi.org/10.1016/j.jacceco.2003.06.003.

Penman, S. (2001). On Comparing Cash Flow and Accrual Accounting Models for Use in Equity Valuation: A Response to Lundholm and O'Keefe. Contemporary Accounting Research, 18(4), 681-692. https://doi.org/10.1506/DT0R-JNEG-QL60-7CBP.

Wild, J., Subramanyam, K.R., \& Hasley, R. (2004). Financial Statement Analysis. New York, NY: McGraw-Hill/Irwin.

Wan, H. (2018). An Empirical Assessment of Alternative Discretionary Accrual Models: Evidence from Earnings Restatements. Accounting and Finance Research, 7(4). https://doi.org/10.5430/afr.v7n4p138. 


\section{Appendix A}

\section{Variable Definitions}

ACC, industry-adjusted total accruals, measured as income before extraordinary items minus CFO;

ATA is the industry-adjusted average total assets;

BIGN is equal to 1 if the firm is audited by a Big N auditor (currently the Big 4), 0 otherwise;

BTD, industry-adjusted temporary book-tax difference, equal to total deferred taxes, grossed up by the statutory tax rate during the sample period (35\%);

CFO_CHG is the original operating cash flows minus the restated operating cash flows deflated by restated total assets.

CHANGE is equal to 1 if a firm's restated total cash flows differs from the originally reported total cash flows, and 0 otherwise;

CURRENT RATIO is the industry-adjusted current assets divided current liabilities;

DEBT is equal to 1 if short-term debt plus long-term debt is greater than the industry median, and 0 otherwise;

DISTRESS is equal to 1 if earnings for the quarter are negative, and 0 otherwise;

DIV is equal to 1 if common dividends paid are greater than the industry median, and 0 otherwise;

DOP is equal to 1 if discontinued operations are greater than the industry-year median value, and 0 otherwise;

DOS is the industry-adjusted discontinued operations;

$|\Delta \mathbf{E} / \Delta \mathbf{C F O}|$ is the industry-adjusted ratio of the absolute value of earnings change to CFO change variable;

FCF, industry-adjusted free cash flow, measured as operating cash flows minus capital expenditures;

IBEScfo is equal to 1 if an analyst issues a cash flow forecast during the fiscal year, and 0 otherwise;

MB is the industry-adjusted market to book ratio;

MBE is equal to 1 if the firm reports earnings which meet or beat the consensus forecast, and 0 otherwise;

NUMSEG is equal to 1 if the number of segments is greater than the industry-year median, and 0 otherwise; 
OPG_CHCF is the change in the amount of restated operating cash flows;

ROA is the industry-adjusted income before extraordinary items divided by total assets;

SIZE is the industry-adjusted log of total assets;

TOTALCHCF is the change in the amount of total cash flows;

UnderSinv is equal to 1 if a firm's restated investing cash flows is less than its originally reported investing cash flows, and 0 otherwise;

UnderSopg is equal to 1 if a firm's restated CFO is less than its originally reported CFO, and 0 otherwise;

UnderStcf is equal to 1 if there is an understatement in total cash flows, and 0 otherwise.

\section{Notes}

Note 1 In some instances, if classification shifting occurs, then we should not see a change in total cash flows with a restatement. However, in $62 \%$ of the sample, we find that changes to total cash flows occur with a CFR, suggesting that more than classification shifting has occurred. We discuss this notion in more detail in the paper.

Note 2. This study examines only CFRs without concurrent earnings or balance sheet restatements. This approach allows us to have a "pure," cash-flow-only restatement sample and allows us to conduct an event study analysis without these confounding effects.

Note 3. Classification shifting occurs when firms shift cash flows between the three cash flow activities (i.e., operating, investing, and financing) within the SCF, but there is no overall change to TCFs.

Note 4. We lost few firms from the sample because of market data unavailability. We also searched for prior disclosures of a CFR announcement for each firm to ensure that we were using the first known disclosure date for our analysis. 